\title{
Corruption in the public health sector in South Africa: A global bioethical perspective
}

\author{
R Rheeder, PhD \\ Department of Moral Development of Society, Faculty of Theology, North-West University, Potchefstroom, South Africa
}

Corresponding author: A Rheeder (riaan.rheeder@nwu.ac.za)

It is clear that corruption as the abuse of power is an enormous bioethical issue in the public health sector in SA, but as a challenge, it has not elicited much discussion from a global bioethical perspective. The Universal Declaration of Bioethics and Human Rights (UDBHR) on corruption considers three matters. First, the existence of corruption as a problem of power is recognised in the health environment and condemned (article 18). Second, corruption is indicated as an immoral phenomenon that harms the interests of the patient (article 4), ignores vulnerable people (article 8) and neglects social responsibility (article 14). Third, it can be concluded that the UDBHR expresses the opinion that corruption has to be combated by a process of ethical decision-making (article 18.2-3), the use of ethics committees (article 19) and ethics education (article 23.1).

S Afr J Bioethics Law 2021;14(3):84-88. https://doi.org/10.7196/SAJBL.2021.v14i3.693

Corruption in all sectors, including public and private healthcare, in democratic South Africa (SA) is truly a serious issue, ${ }^{[1]}$ and forms the basis of the problem statement in this study. Corruption is defined as 'the abuse of resources, power and/or connections for private gain' ${ }^{[2]}$ In one of few empirical studies on the phenomenon of corruption in the public health sector in SA, Rispel et al. ${ }^{[2]}$ reached the following conclusions:

- Corruption is on the increase, which is confirmed by the fact that health departments received an increasing number of 'qualified audits' during the period $2004-2013{ }^{[3]}$ This means that'the financial statements contain material misstatements in specific amounts, or there is insufficient evidence for the auditor to conclude that specific amounts included in the financial statements are not materially misstated! [2]

- Approximately ZAR24 billion is deemed to be irregular expenditure for all the provinces together for (only) the period 2009 - 2013. Irregular expenditure is defined as follows by the annual reports of the auditor general of SA:'expenditure incurred without complying with applicable laws and regulations', but Rispel et al. ${ }^{[2]}$ point out that 'notwithstanding the fact that irregular or unprocedural spending does not always result in personal gain, corruption of necessity involves "irregular or unprocedural activities".["[]

Between April 2020 and June 2021, total COVID expenditure by government departments exceeded ZAR138 billion. Of this, ZAR14.8 billion (>10\%) is under investigation by the Special Investigating Unit (SIU). One among many examples of corruption is the procurement of personal protective equipment (PPE) from unlicensed suppliers (IT firms, travel agencies, events and catering businesses, construction and engineering companies, transport and logistics operators, solar power installers and even auto repair shops). PPE is needed to protect health workers who risk their lives on the frontlines of SA's fight against COVID-19. The heartbreaking consequence of using unlicensed suppliers is the inferior quality of PPE products (masks received were the wrong shape and did not fit very well) and price-gouging (up to five times the normal price), while some hospitals found that state-purchased PPE never reached them or the staff at all. ${ }^{[4-6]}$

TimesLive reported on 3 July 2017 that SA had received a very poor ranking on the Social Progress Index. This index measures and compares different countries with one another based on indicators such as the outcomes of nutrition and basic medical care provided. According to the index, SA received a score of 83 out of 128 in 2017, where the score of 1 was the best and 128 the worst. The reasons for this poor outcome, according to Prof. Jerry Coovadia of the Active Citizens Movement, are corruption and mismanagement. ${ }^{[3,7]}$ Corruption Watch ${ }^{[8]}$ reports that it received a large and increasing number of complaints about corruption in the public health sector during the first 6 months of 2018. In a 2018 report, the South African Institute of Race Relations (SAIRR) states the following: 'state capture and corruption were identified as the primary risk factor to the SA public health system. ${ }^{[3]}$ This statement of the SAIRR is confirmed by the fact that the Special Investigating Unit has launched a new programme that will focus specifically on corruption, waste and fraud in the public health sector, because the sector is suspected of extensive corruption and is regarded as the area most vulnerable to corruption. ${ }^{[3]}$ There are now so many allegations of corruption under investigation by the SIU that the 2021 report to Parliament's Standing Committee on Public Accounts took up 118 PowerPoint slides and 2-and-a-half hours. ${ }^{[6]}$

Corruption has heart-rending consequences. Apart from the loss of hard-earned tax money, it leads to damage to the health of patients, and even death. ${ }^{[9]}$ Rispel et al. ${ }^{[2]}$ refer to an example in which a tender by the Gauteng Department of Health $(\mathrm{GDoH})$ was allocated to a private 
company to provide a hospital with beds. The company's selling price was twice the amount of the closest bid, although the beds were of very poor quality. It thus happened that a surgical bed broke during a caesarean operation, which resulted in the mother's skull being broken. Mark Heywood ${ }^{[10]}$ of SECTION27 writes: 'The worst example of the results of corruption is the Life Esidimeni disaster, which caused the death of at least 143 mental health patients', and according to some lawyers, can be described as 'SA's worst human rights abuse since the end of apartheid! ${ }^{[10]}$ Under the supervision of Member of the Executive Council Qedani Mahlangu, psychiatric patients were mercilessly dumped in unregistered, incompetent and poorly equipped non-governmental organisations (NGOs). Many of these NGOs received illegal licences in a fraudulent way. Although they received no site inspection, they were paid thousands in ZAR. Patients died of neglect, starvation, dehydration, thirst and suffocation in their own blood. Information indicates that some senior officials for mental health in the GDoH had corrupt relationships with some of the NGOs, ${ }^{[10]}$ which is probably one of the reasons why the choice of specific NGOs is described by Prof. Malegapuru Makgoba, ${ }_{1}^{[1]}$ the ombudsman for health, as 'mysteriously selected'. Proof has also been found that some of the NGOs benefited from the disability grants and life insurance of the patients, some of whom were deceased. ${ }^{\left[{ }^{[10]}\right]}$ It is clear that corruption, as the abuse of power, is a huge bioethical issue in the public health sector in SA.

Against the above background, the aim of this brief investigation is to create a heightened awareness of corruption in SA, and to fight it by presenting an academic global bioethical perspective on it. Social scientists point out that there is an abundance of anti-corruption laws, rules and regulations in $\mathrm{SA}$; in addition, a variety of other suggestions have been made for fighting corruption. ${ }^{[9]}$ These possibilities will not be discussed here, but the emphasis will now rather be on what methods global bioethics offers to combat corruption. To achieve this aim, corruption will be measured against relevant global bioethical principles set out in the Declaration of Bioethics and Human Rights (hereafter UDBHR) of the United Nations Educational, Scientific and Cultural Organization (UNESCO). ${ }^{[12]}$ The phenomenon of corruption as a bioethical challenge in SA has not been subjected to in-depth evaluation from a global perspective. ${ }^{[13]}$ From the above discussion flows the research question, namely, whether a global bioethical evaluation of corruption can be found. The central theoretical statement of the present study is that a global bioethical perspective on corruption does indeed exist, and the aim of this study is to demonstrate the theoretical statement.

\section{A global bioethical perspective UNESCO and UDBHR}

What is the point of departure of a global perspective on corruption in SA? The point of departure in the evaluation in this study is the UDBHR, as accepted by the member states of UNESCO in 2005..$^{[12]}$ Miller and English ${ }^{[14]}$ emphasise that it is very valuable as an ethical and human rights instrument to evaluate corruption from a global perspective:

'The UDBHR provides a particularly useful expression of such standards, and many problems of corruption can be understood as deviations from core ethical principles articulated in the document ... Frameworks such as the declaration perform a valuable service in articulating common standards that can act as criteria for diagnosing corruption.
The study of corruption is a new theme in the scope of global bioethics, which means that few scientists have given attention to the subject. ${ }^{[15]}$ Because only two articles could be found that see common ground between the UDBHR and corruption, this discussion should be regarded as a tentative evaluation.

Why use the UDBHR in particular? The UDBHR was consented to unanimously by all member states in 2005, which means that the declaration with its global bioethical principles was the first in the history of global bioethics, and currently the only bioethical and political text to which all the states in the world, including SA, have committed themselves. ${ }^{[16]}$ This acceptance means that the instrument and relevant principles do not only have symbolic value, but are meant and accepted as an instrument with moral authority and obligations that should be taken very seriously. ${ }^{[17,18]}$ The fact that bioethical principles and norms are presented in human rights terms strengthens the moral appeal of the declaration. ${ }^{[19]}$ In the UDBHR, South Africans have a global consensus about bioethical principles that may be relevant in evaluating corruption in their country.

What is the scope of the UDBHR? From the title of the declaration, it can be concluded that the instrument intends to present a global or universal perspective on bioethical problems. In other words, it proposes that this is the way the world, i.e. all member states of UNESCO together, evaluates bioethical phenomena and problems such as corruption. Article 1 indicates that the instrument addresses bioethical matters that relate to health and society (article 1.1). ${ }^{[12]}$ In addition, article 1 indicates the declaration does not only address the state, but also individuals, groups, communities, institutions and corporations in the public and private sphere (article 1.2). ${ }^{[12]}$ Corruption does indeed concern medicine, health and people in their social, juridical and health environment. ${ }^{[18]}$

What objectives are stated by the UDBHR? Article 2 states eight objectives. The second states that the declaration has the objective of guiding the behaviour of individuals, groups, communities, institutions and corporations in the public and private sphere (article 2b). ${ }^{[12]}$ The third objective states the instrument wants to promote respect for human dignity and protect human rights (article $2 \mathrm{c}$ ). ${ }^{[12]}$ The fifth objective (article 2e) expresses the need for 'a pluralistic dialogue about bioethical issues between all stakeholders and within society as a whole! ${ }^{\prime 20]}$ It means that the perspective of the UDBHR on corruption has the purpose of transforming behaviour by means of dialogue in such a way that human dignity will be promoted.

\section{Corruption condemned}

What perspective does the UDBHR offer on corruption? The word 'corruption' is not found in the UDBHR, but according to Hamdan, ${ }^{[21]}$ the subject of corruption is found in the declaration where article 18.1 ('Decision-making and addressing bioethical issues') states: 'Professionalism, honesty, integrity and transparency in decisionmaking should be promoted, in particular declarations of all conflicts of interest and appropriate sharing of knowledge. ${ }^{[12,14]}$ Miller and English ${ }^{[14]}$ share the opinion of Hamden, saying:

'Conflicts of interest are perhaps the most studied form of corruption in bioethics, and there is an expansive literature considering their nature, effects, and possible remedies (article 18).

The UDBHR itself also does not offer a definition of corruption, but recommends in the foreword that other relevant United Nations 
declarations may be used as an interpretative context for the UDBHR. In this connection, the 2004 United Nations Convention against Corruption ${ }^{[22]}$ is relevant. Article 19 ('Abuse of functions') understands corruption as 'the abuse of [...] position [...] by a public official [...] for the purpose of obtaining an undue advantage for himself or herself'.

What global bioethical and human rights judgment on corruption does the UDBHR offer? Mammadova and Mammadov ${ }^{[18]}$ explain the perspective as follows:

'Corruption in healthcare is not only illegal but also immoral, encroaching on the highest intangible benefits (life and health), far from civilized relations in society. It contradicts the principles of medical deontology and medical ethics and infringes directly, or indirectly, upon the application of the basic bioethical principles set forth in the Universal Declaration on Bioethics and Human Rights of 2005.

Corruption is a transgression of several global bioethical and human rights, as set out in the UDBHR. ${ }^{[14]}$ Although corruption violates all the global-ethical principles in the UDBHR, articles 4,8 and 14 are among the most important principles opposing corruption. ${ }^{[14]}$ The first principle in conflict with corruption is found in article 4, which states the following: 'In applying and advancing scientific knowledge, medical practice and associated technologies, direct and indirect benefits to patients, research participants and other affected individuals should be maximised and any possible harm to such individuals should be minimised.' From the abovementioned serious suspicion of irregular expenditure in the Life Esidimeni tragedy, it is clear that corruption harms citizens in a shocking manner.

The second principle contradicting corruption is found in article 8, which states: 'In applying and advancing scientific knowledge, medical practice and associated technologies, human vulnerability should be taken into account. Individuals and groups of special vulnerability should be protected and the personal integrity of such individuals respected.' Vulnerability refers to the inability to promote and protect one's own interests. ${ }^{[19]}$ This global principle means that where vulnerable people are concerned, strict protocols have to be followed, and extremely careful and discerning decisions made. The Life Esidimeni tragedy demonstrates that corruption was the very reason that vulnerable people received almost no or very poor protection, which led to the grave violation of their personal integrity. The third principle contrary to corruption is found in article 14.1, which states that 'the promotion of health and social development for their people is a central purpose of governments that all sectors of society share.'From the above brief discussion of the serious suspicion of corruption, it is clear that corrupt actions definitely do not promote the health of people, but rather harm it.

\section{Corruption challenged}

Having rejected corruption as unethical, what should be done about it, according to the UDBHR? Article 18 of the UDBHR not only exposes and condemns corruption, but also advocates the fight against corruption ${ }^{[21]}$ From its title ('Decision-making and addressing bioethical issues') it can be deduced that this principle concerns two matters, namely decision-making and addressing bioethical problems. The first matter to which special attention is given is a process of ethical decision-making, as deduced from the words 'in decision-making' in article 18.1. The process of decision-making (e.g. in the procurement of hospital beds) has to be guided by the following six global bioethical norms, namely: (i) professionalism (ii) honesty; (iii) integrity; (iv) transparency; (v) non-corruption; and (vi) sharing information (see article 18.1)

Professionalism means that competent people, with adequate training, knowledge and experience, should definitely be part of the decision-making process. Inadequacy in this respect frequently leads to decisions that do not consider moral principles and the interests of others. Honesty means that information on the matter about which a decision has to be made should not be falsified, fabricated or concealed with the aim of promoting self-interests. ${ }^{[23]} \mathrm{Is}$ it, for example, known that the beds are made of poor-quality steel and are not the correct size? Integrity, on the one hand, indicates the personal quality of strong moral principles, and on the other hand, a state of wholeness and indivisibility. ${ }^{[24]}$ It indicates coherent behaviour and decisions, which means that conflict or division should not occur between the undertaking of the official to promote the interests of the (public) institution and the real decision. Should a person continue to procure hospital beds of poor quality despite the fact that this does not promote the interests of the hospital and public? Transparency is 'a very important condition for principled decisionmaking and sound practice within bioethics, ${ }^{\prime 21]}$ and in practice these should not be allowed to take place in secret, but as far as possible, must be accessible and open so that all the people involved are aware of them. Is everyone in the department and hospital informed about how the hospital beds are going to be procured?

Conflict of interest refers to 'a situation in which a person is in a position to derive personal benefit from actions or decisions made in their official capacity!'25] This norm appeals to the decision-maker to state any conflict of interest and, if there should be any such conflict, (s)he should withdraw from the decision-making process. ${ }^{[2]]}$ If one has shares in a company that has offered a tender to supply beds to the hospital, one must declare that interest and withdraw from the decision-making process. Finally, no decision can be made without the appropriate and relevant information; therefore, article 18 recommends that the best scientific and relevant information is available to all during the decision-making process. ${ }^{[2]}$ A question that could be asked is whether the available beds comply with the minimum standards deemed beneficial to patients.

The second way in which corruption can be opposed ('addressing bioethical issues') is described in article 18.2-3, which reads as follows: 'Persons and professionals concerned, as well as society as a whole, should be engaged in dialogue on a regular basis. Opportunities for informed pluralistic public debate, seeking the expression of all relevant opinions, should be promoted.'12]

Miller and English ${ }^{[14]}$ explain the relevance of the article to corruption as follows:

'Attempting to persuade those involved in a corrupt practice of its vices is an important enterprise, as is trying to dialogue with and persuade the larger public (article 18). This is why documents such as UNESCO's UDBHR are so useful.'

Article 18.2-3 is a plea for dialogue and debate (see 'engaged in dialogue' and 'pluralistic public debate') on certain challenges in bioethical context. Professional persons ('persons and professionals') in the health environment and in society as a whole have to participate 
in this dialogue ('society as a whole'). What professional people and the community have in common is concern ('concerned') about bioethical problems. The dialogue and debate have to focus among other things on possible corruption ('in particular declarations of all conflicts of interest') and have to take place regularly ('periodically; regular basis'). A dialogue can take place in various ways, among other means via academic articles, journalism and civil society. ${ }^{[21]}$ The value of dialogue regarding a specific bioethical issue such as corruption is that it appeals to the individual and the state to assume responsibility (see article 5 of UDBHR). ${ }^{[12]}$

Third, article 19 of the UDBHR is regarded as the next defence against corruption ('addressing bioethical issues'). ${ }^{[12,18]}$ It deals with the possible establishment of ethics committees in hospitals, clinics, state departments and other health sectors. According to the declaration (article 22.2), one of the responsibilities of the state is to promote the institution of ethics committees. ${ }^{[12]}$ This means that the authority of supervision is entrusted to or at least shared by a third party. Article 1.2 states the scope of the declaration, indicating that it among other factors 'provides guidance to decisions or practices of individuals, groups, communities, institutions and corporations, public and private, and links up with article 19(b), which says that one of the objectives of the ethics committee should be to 'provide advice on ethical problems in clinical settings.'112] The credibility of an ethics committee is determined and strengthened by the fact that, according to article 19.1, the committee has to be independent, multidisciplinary and pluralistic in nature. ${ }^{[12,20]}$ The implications are that health departments could seriously consider ethics committees to help with guidance and advice on, among other issues, saving money and considering projects and appointments. Two matters determine the advice and guidance provided by ethics committees. The first is that article 18 is presented under the heading, 'Application of the principles', which indicates that the ethics committee will have to test or measure all decisions in the health department against the global bioethical principles of the declaration to ascertain whether all the managerial decisions comply with universal values. ${ }^{[2]]}$ A second special function of the ethics committee, according to article 20 of the UDBHR, is to perform 'appropriate assessment and adequate management of risk related to medicine.$^{\prime[12,20]}$ This principle also has to be applied in healthcare systems, which means that the ethics committee has to make sure that the possible risks of any decision in the health sector are analysed effectively according to the best information available and using the best scientific methods. ${ }^{[26]}$ When any decision poses a high risk to health, the decision has to be opposed.

According to Mammadova and Mammadov, ${ }^{[18]}$ one of the most important weapons against corruption ('addressing bioethical issues') is found in article 23.1, which states the following:

In order to promote the principles set out in this Declaration and to achieve a better understanding of the ethical implications of scientific and technological developments, in particular for young people, States should endeavour to foster bioethics education and training at all levels as well as to encourage information and knowledge dissemination programmes about bioethics.'12]

Mammadova and Mammadov ${ }^{[18]}$ are convinced that bioethical education and training is an important medium and long-term strategy to combat corruption. States have to consider promoting bioethical education and training programmes, especially among young people. According to these two jurists, human nature is intent on its own interest and benefit, and therefore ethical education building up an ethical life- and worldview has to start as soon as possible. An 'ethical anti-corruption worldview' has to be developed among young people. With reference to article 23.1, this education has to give attention to two matters in particular. The first is the ethical content as found in the 15 articles of the UDBHR. Second, the declaration states that understanding the consequences of unethical actions should be set out 'to achieve a better understanding of the ethical implications of scientific and technological developments'. The emphasis here is placed on the ethical implications of bioethical challenges such as scientific and technological development, but the ethical implications of bioethical problems such as corruption are not excluded.

\section{Conclusion}

It is clear that corruption as the abuse of power is an enormous bioethical issue in the public health sector in SA, but as a challenge, it has not elicited much discussion from a global bioethical perspective. The perspective of the UDBHR on corruption consists of three matters: first, the existence of corruption as a problem of power is recognised in the health environment and condemned (article 18). Second, corruption is indicated as an immoral phenomenon that harms the interests of the patient (article 4), ignores vulnerable people (article 8) and neglects social responsibility (article 14). Third, it can be concluded that the UDBHR expresses the opinion that corruption has to be combated by a process of ethical decision-making (article 18.2-3), the use of ethics committees (article 19) and ethics education (article 23.1).

Acknowledgements. None.

Author contributions. Sole author.

Funding. None.

Conflicts of interest. None.

1. Vorster JM. Managing corruption in South Africa: The ethical responsibility of churches. Scriptura J Contex Hermeneutics South Afr 2012;109(1):133-147. https://doi.org/10.7833/109-0-130

2. Rispel L, de Jager P, Fonn S. Exploring corruption in the South African health sector. Health Pol Planning 2016;31(2):239-249. https://doi.org/10.1093/heapol/czv047

3. Roodt M, Fleming M. South Africa's National Health Insurance scheme. Johannesburg: South African Institute of Race Relations, 2018. https://irr.org.za/ reports/occasional-reports/files/sa-nhi-scheme.pdf (accessed 16 January 2019).

4. Myburgh PL. SA's R2bn unlicensed emergency PPE bombshell. Daily Maverick, 2 October 2020. https://www.dailymaverick.co.za/article/2020-10-02-sas-r2bnunlicensed-emergency-ppe-bombshell/ (accessed 7 October 2021).

5. Heywood M. Scandal of the year: Covid-19 corruption. Daily Maverick, 27 December 2020. https://www.dailymaverick.co.za/article/2020-12-27-scandalof-the-year-covid-19-corruption/ (accessed 7 October 2021).

6. Heywood M. Covid-19 corruption tops R14-billion but to bust criminals we need to drastically boost prosecution services and courts. Daily Maverick 21 September 2021. https://www.dailymaverick.co.za/article/2021-09-21-covid19-corruption-tops-r14-billion-but-to-bust-criminals-we-need-to-drasticallyboost-prosecution-services-and-courts/ (accessed 7 October 2021).

7. Govender S. SA good on tolerance but fails on health and safety. Johannesburg: Tiso Blackstar Group, 2017. https://www.timeslive.co.za/news/southafrica/2017-07-03-sa-good-on-tolerance-but-fails-on-health-and-safety/ (accessed 16 January 2019)

8. Corruption Watch. Corruption in the health sector. Act Report 2018. Johannesburg: Corruption Watch, 2018. https://www.corruptionwatch.org.za/ wp-content/uploads/2018/08/Corruption-Watch-ACT-Report-2018-eBook-OUTAgent-Orange-Design-07082018.pdf (accessed 16 January 2019).

9. Pillay P, Mantzaris EA. Corruption in the health sector in South Africa and India: Some considerations and reflections. Afr J Pub Affairs 2017(8):48. https://hdl. handle.net/10520/EJC-ab509a6cb (accessed 22 October 2018). 
10. Heywood M. State capture threatens the right to health. SECTION27, 2017. https:// www.spotlightnsp.co.za/2017/11/30/state-capture-threatens-right-health/ (accessed 16 January 2018).

11. Makgoba MW. The report into the 'circumstances surrounding the deaths of mentally ill patients: Gauteng Province'. No guns: $94+$ silent deaths and still counting. Pretoria: Health Ombud, 2017. http://ohsc.org.za/wp-content/uploads/2017/09/ FINALREPORT.pdf (accessed 16 January 2019).

12. United Nations Educational, Scientific and Cultural Organization. Universal Declaration on Bioethics and Human Rights. Paris: UNESCO, 2006. http://unesdoc. unesco.org/images/0014/001461/146180e.pdf (accessed 13 November 2013).

13. Langlois A. Negotiating Bioethics: The Governance of UNESCO's Bioethics Programme. New York: Routledge, 2013.

14. Miller JE, English W. Corruption. In: Ten Have H, Gordijn B (editors). Handbook of Global Bioethics. Dordrecht: Springer Science and Business Media, 2014:599-618.

15. Ten Have H, Gordijn B. Structure of the compendium. In: Ten Have H, Gordijn B, (editors). Handbook of Global Bioethics. Dordrecht: Springer Science and Business Media, 2014:35-41.

16. Ten Have H, Jean M. Introduction. In: Ten Have H, Jean M (editors). UNESCO Universal Declaration on Bioethics and Human Rights: Background, Principles and Application Ethics Series. Paris: UNESCO, 2009:17-57

17. Ten Have H. Foundationalism and principles. In: Chadwick R, Have $\mathrm{H}$, Meslin EM, (editors). The SAGE Handbook of Health Care Ethics: Core and Emerging Issues. Thousand Oaks: SAGE Publications, 2011:454

18. Mammadova VY, Mammadov VG. Violations of United Nations bioethics and human rights declarations by corruption in the health. Med Law 2018;37(2):285-296.

19. Ten Have H. Global Bioethics: An Introduction: New York:Taylor \& Francis Group, 2016.
20. Huriet C. Article 19: Ethics committees. In: Ten Have $\mathrm{H}_{\text {, Jean } M}$ (editors). UNESCO Universal Declaration on Bioethics and Human Rights: Background, Principles and Application Ethics Series. Paris: UNESCO, 2009:265-270.

21. Hamdan MA. Decision-making and addressing bioethical issues. In: Ten Have $\mathrm{H}$, Jean M (editors). UNESCO Universal Declaration on Bioethics and Human Rights: Background, Principles and Application Ethics Series. Paris: UNESCO, 2009:255-263.

22. United Nations Office on Drugs and Crime. United Nations Convention Against Corruption. Vienna: Vienna International Centre, 2004. https://www.unodc. org/documents/treaties/UNCAC/Publications/Convention/08-50026 E.pdf (accessed 16 January 2018)

23. Resnik DB. Scientific misconduct and research integrity. In: Ten Have HAM , Gordijn B (editors). Handbook of Global Bioethics. Dordrecht: Springer Science and Business Media, 2014:799-810.

24. Rendtorff JD. European perspectives. In: Ten Have H, Gordijn B, (editors) Handbook of Global Bioethics. Dordrecht: Springer Science and Business Media, 2014:293-310.

25. Xie G, Cong Y. Conflict of interest. In: Ten Have H (editor). Encyclopedia of Global Bioethics. New York: Springer International Publishing, 2016:725-729.

26. Jean M. Article 20: Risk assessment and management. In: Have $H_{\text {, Jean } M}$ (editors). UNESCO Universal Declaration on Bioethics and Human Rights: Background, Principles and Application Ethics Series. Paris: UNESCO, 2009:271-282.

Accepted 19 November 2021 